\title{
Split Payment VAT Collection Mechanisms and Their Impact on the EU Market of Payment Technologies and Services
}

\author{
Konrad Stolarski \\ Krakow University of Economics, Faculty of Finance and Law, Poland \\ Partner and attorney at law at FinTaxLegal, Poland \\ konrad.stolarski@uek.krakow.pl
}

\begin{abstract}
The paper presents a critical assessment of how contemporary attempts to eliminate the VAT gap through alternative methods of VAT collection like the Split payment VAT collection mechanism can impact the EU markets of payment services and payment processing. The article in particular analysis how the current 'fintech' revolution observed in the EU and the introduction of new services like payment initiation can be affected of even potentially favorized by VAT tax regulation in comparison to historically more traditional online acquiring services.
\end{abstract}

Keywords: VAT, split payment, fintech, PSD2

\section{Introduction}

Recent years of regulatory developments in Europe show significant activity of both national as EU authorities in the scope of tax law and financial law. Whereas however the latter has been very heavily affected by EU legislation, tax law itself despite ambitious plans and correct assessment of the problems troubling the EU markets in the content of numerous reports and communications published over the years $^{1}$, has not been met with equal attention. This is naturally understandable to some extent, given the legal basis for legislative intervention given in the EU Treaties ${ }^{2}$. As it will however be outlined below, the dynamic evolution of the EU market of financial services and the both country specific as well as EU-wide developments in the field of tax law (especially in the area of value added tax) definitely intercede, both conceptually as well as on the practical stage of application of law.

\section{Pan European fintech (re)volution}

The origins of the sudden widespread of fintech services should be traced back to the post 2008 crisis environment when trust in banking was heavily shaken in the eyes of the market and consumers ${ }^{3}$. Fintech or financial technology (as it was called back in the days when today's abbreviation was not yet so common) services started to be considered by many as an alternative to traditional banking. The surging popularity of new services paved the way for the adoption of new EU legislation intended both to foster the newcoming innovations as well as to safeguard the adequate financial standing of the entities offering them and secure the safety of client funds which were being entrusted to them. Among the most important legislative developments in this respect one should consider above all the Electronic Money

\footnotetext{
${ }^{1}$ See in particular: Communication from the commission to the European Parliament, the Council and the European Economic and Social Committee on the future of VAT: Towards a simpler, more robust and efficient VAT system tailored to the single market, 2011, Brussels, 6.12.2011, COM(2011) 851 final and the Communication from the Commission to the European Parliament, the Council and the European Economic and Social Committee on an action plan on VAT: Towards a single EU VAT area - Time to decide (2016), Brussels, 7.4.2016, $\operatorname{COM}(2016) 148$ final.

${ }^{2}$ See art. 113 of the Treaty on the functioning of the European Union.

${ }^{3}$ Stolarski, K. 2018, 'Bank account infrastructure as an indispensable means to provide financial services - the essential facilities doctrine revisited.' European Competition Law Review 39 (3), p. 125, Mackenzie A. 2015 'The fintech revolution’, London Business School Review 26(3), p. 50.
} 


\section{Mic 2019 \\ Opatija, Croatia • 29 May-1 June 2019}

Directive $^{4}$, the Payment Services Directive ${ }^{5}$ and its legal successor, the second Payment Services Directive $^{6}$. Whereas the PSD and the EMD levelled the playing field and placed the world of new nonbank payment services activity under financial supervision of national authorities, the PSD2 followed this path, adding stricter rules, market regulation and introducing a whole new open banking reality ${ }^{7}$ along with the widening of the catalogue of payment services with two new innovative ones - account information ${ }^{8}$ and payment initiation ${ }^{9}$, i.e. services offered by so called 'third party providers' (TPPs). The 'innovative' character of these two new services was by the way one of the biggest controversies in the process of their introduction, due to the additional (in comparison to traditional alternatives) risks their activity creates ${ }^{10}$. Unlike traditional payment services, the two latter do not envisage their provider to enter into possession of the users' funds. What happens instead, is that the PIS/AIS providers, acting within the consent granted to them by the user, enter into possession of the users' login credentials and password to the e-banking environment and act as their intermediary to either:

A. offer an online service of provision of consolidated information on one or more payment accounts held by the payment service user with either another payment service provider or with more than one payment service provider (AIS) ${ }^{11}$; or

B. initiate a payment order at the request of the payment service user with respect to a payment account held at another payment service provider (PIS) ${ }^{12}$

Since only the latter service involves transactional activity, it is only that among the two which will be the further focus of this paper, due to its practical importance for the subject matter of this article.

\section{Difference between transaction processing in online payments in the traditional acquiring model and the PIS model}

As indicated above, in the traditional model of online payments, be it in the card or credit transfer model, all include the key element of the acquirer (payment service provider) entering into possession of funds as the intermediary between the user and the merchant in the course of the transaction. The flow of such a transaction, in the so called 'pay by link' (PbL) model, can be illustrated with the following diagram:

\footnotetext{
${ }^{4}$ Directive 2009/110/EC of the European Parliament and of the Council of 16 September 2009 on the taking up, pursuit and prudential supervision of the business of electronic money institutions amending Directives 2005/60/EC and 2006/48/EC and repealing Directive 2000/46/EC (“EMD”).

${ }^{5}$ Directive 2007/64/EC of the European Parliament and of the Council of 13 November 2007 on payment services in the internal market amending Directives 97/7/EC, 2002/65/EC, 2005/60/EC and 2006/48/EC and repealing Directive 97/5/EC ('PSD').

${ }^{6}$ Directive (EU) 2015/2366 of the European Parliament and of the Council of 25 November 2015 on payment services in the internal market, amending Directives 2002/65/EC, 2009/110/EC and 2013/36/EU and Regulation (EU) No 1093/2010, and repealing Directive 2007/64/EC ('PSD2').

${ }^{7}$ On the opportunities and threats of open banking see: Mansfield-Devine, S. 2016, 'Open banking: opportunity and danger', Computer Fraud \& Security (10), pp. 8-13.

${ }^{8}$ Pt. 8 of Annex I of the PSD2.

${ }^{9}$ Pt. 7 of Annex I of the PSD2.

${ }^{10}$ On these risks see in particular: de la Mano, M. and Padilla J. 2019, 'BIG TECH BANKING', Journal of Competition Law \& Economics, 14(4), p. 503-504.

${ }^{11}$ See art. 4.16 of the PSD2.

${ }^{12}$ See art. 4.15 of the PSD2.
} 


\section{(Mic 2019 \\ Management International Conference \\ Opatija, Croatia • 29 May-1 June 2019}

Diagram 1: Transaction flow in online POS acquiring

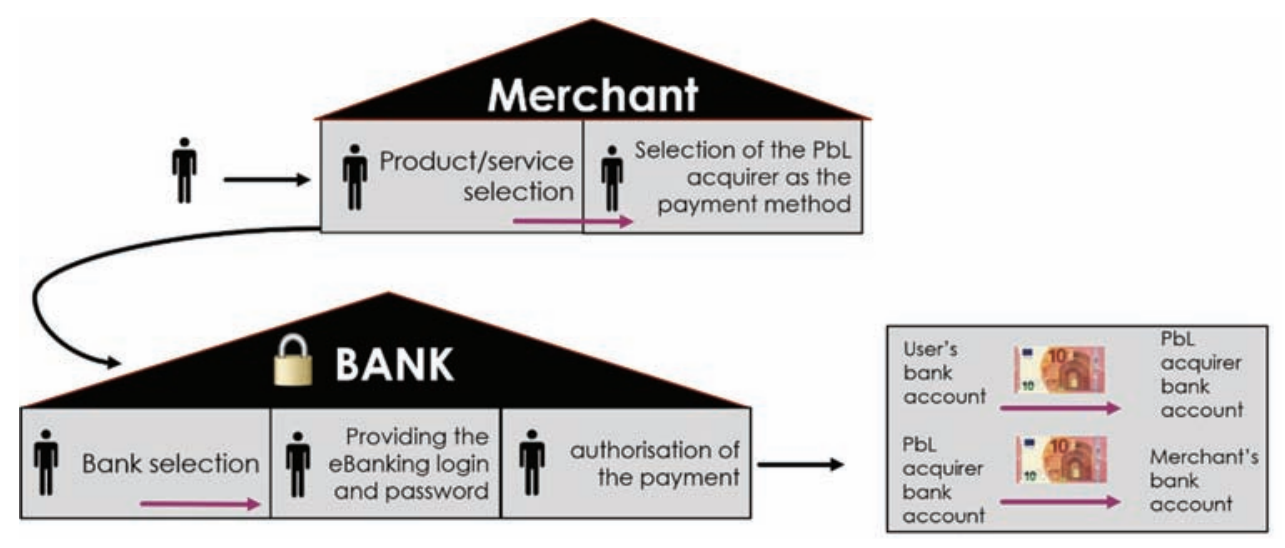

In the PIS model on the other hand the PIS provider does not enter into possession of funds on any of the stage of the execution of this service (what however does not exclude him from the possibility of entering into possession of funds in the course of providing other payment services complementary with PIS, e.g. payment account services, if the license granted to him includes such services). In turn, it is the PIS provider himself, who - using the user's e-banking login and credentials - submits the payment order to have the user's funds transferred to the bank account of the merchant. The transaction flow in the PIS model is presented in the following diagram:

Diagram 2: Transaction flow in online the PIS model

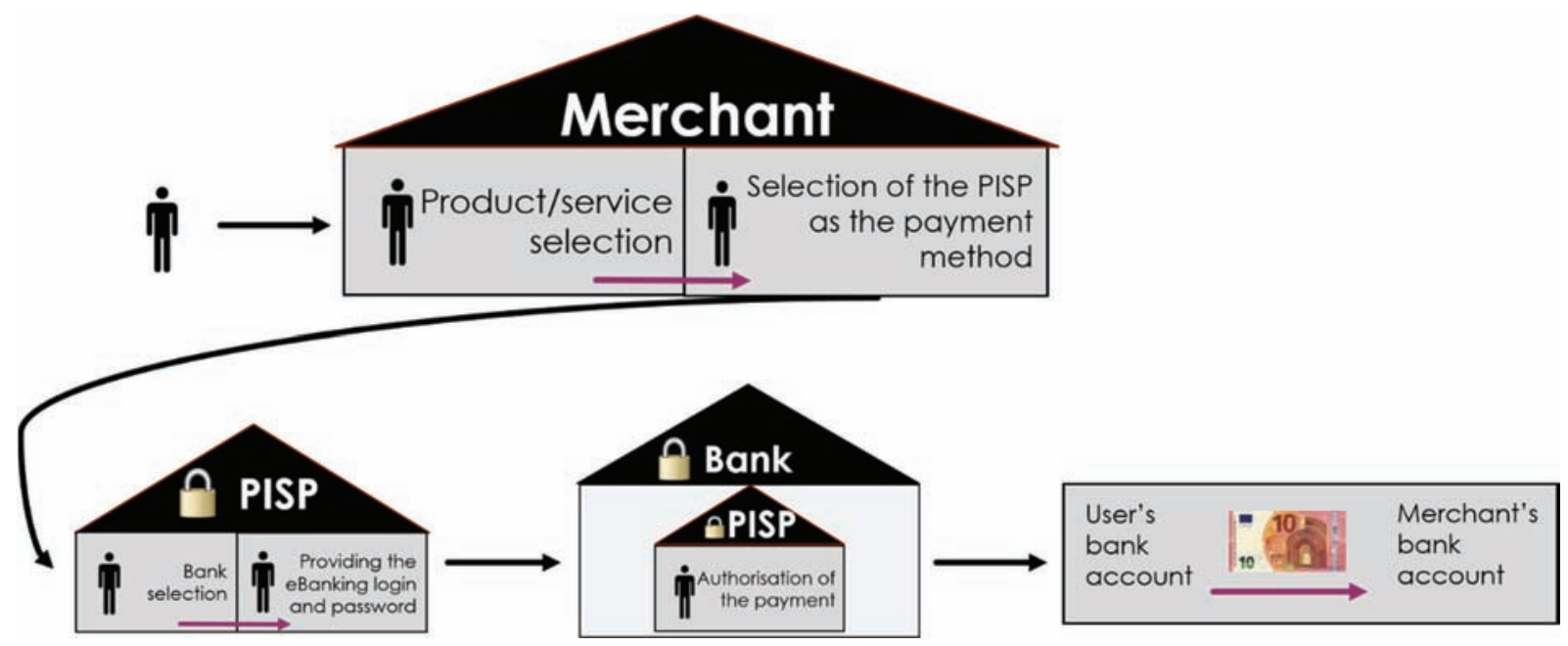

\section{Why is the VAT collection mechanism important from the perspective of online payment technologies?}

It has long been indicated that the spread of e-commerce poses a serious challenge to existing systems of direct and indirect taxation ${ }^{13}$. One might consider that given the VAT approach to financial transactions applied in the EU, any differences between the construction of payment transaction processing technologies would remain rather indifferent on the VAT materia. Indeed financial services

\footnotetext{
${ }^{13}$ See in particular Paris R. 2003. 'The Globalization of Taxation? Electronic Commerce and the Transformation of the State’, International Studies Quarterly (2003) 47, 153-182.
} 
have long been exempt from VAT, what is currently sanctioned by art. 135.1.(d) of the VAT Directive ${ }^{14}$ and this approach is basically followed by almost all OECD nations ${ }^{15}$. In recent years however the main topic behind any VAT reform debated both on the EU and member states level has always focused around the main objective, which is the reduction of the VAT gap, i.e. the VAT revenues which should have been collected, but have not been due to fraud and illegal tax evasion. The study and report prepared for the Directorate General of Taxation and Customs Union of the European Commission estimated that the overall VAT gap in the 28 EU states although declined in comparison to previous years, in 2016 still amounted to $€ 147.1$ billion $^{16}$. The European Commission itself simultaneously pressures for the creation of a single EU VAT area which would help to shut down the estimated $€ 50$ billion in fraud currently annually affecting national budgets in EU Member States ${ }^{17}$ and regularly proposes changes in the VAT Directive aiming at the reduction of this number ${ }^{18}$. Since there has yet to been however developed a complex resolution of the VAT gap problem on the EU level, member states themselves try to implement their own ideas for optimizing VAT collection.

\subsection{Split payment for collection of VAT as a response to the VAT gap}

Due to the aforementioned problems with the VAT gap in the EU, member states have long debated alternative VAT collection methods that could help eliminating VAT fraud. As a first measure we have seen legislative changes resulting in adding of additional reporting obligations intended to facilitate tax control and tax compliance enforcement. Apart from this however the standard VAT system has been also modified with the possibility to hold the recipient of the taxable supply liable for the applicable VAT, instead of the supplier and an option for the recipient to secure VAT and send it directly to the tax officers instead of paying it to the supplier within the price of purchased goods or services ${ }^{19}$.

One of the measures intended to address the VAT cap on national level is the so called VAT split payment collection system. To date in the EU, various forms of split payment VAT collection have been implemented in Italy, Czechia, Romania and Poland. Particular models of implementation differ between countries ${ }^{20}$, but the main objective is basically the same. In each of its forms, the VAT split payment mechanism aims at the tightening of the fiscal system and increasing the security of the business turnover ${ }^{21}$, through the separation of the NET invoice value form the applicable VAT tax rate value and their transfer to two separate accounts. The first EU split payment mechanism was introduced in Italy and became applicable as of 1 January 2015. Italian provisions require the VAT amount invoiced by the seller to be paid directly to the tax authorities by the buyer (recipient of the invoice) and is

\footnotetext{
${ }^{14}$ Council Directive 2006/112/EC of 28 November 2006 on the common system of value added tax.

15 This is however not to say that a different approach has not been debated, and voices against the VAT exemption for financial services have not been raised. For a complex overview of the reasons and rationale behind the VAT exemption for financial services see Huizinga, H. 2002,'A European VAT on financial services?', Economic Policy 17(35), pp. 497-534.

${ }^{16}$ Study and Reports on the VAT Gap in the EU-28 Member States: 2018 Final Report TAXUD/2015/CC/131, published in Warsaw, Poland on September $11^{\text {th }} 2018$, available at https://ec.europa.eu/taxation_customs/sites/taxation/files/2018_vat_gap_report_en.pdf, p. 8.

${ }^{17}$ See i.a. the Communication from the Commission to the European Parliament (2016)...

${ }^{18}$ The most recent of which include the so called "quick fixes package" introduced by Council Directive (EU) 2018/1910 of 4 December 2018 amending Directive 2006/112/EC as regards the harmonisation and simplification of certain rules in the value added tax system for the taxation of trade between Member States, entering into force on 1 January 2020.

${ }^{19}$ See Zídková H, Št’astná A. 2019. 'VAT Collection Methods'. Acta Universitatis Agriculturae et Silviculturae Mendelianae Brunensis, 67(3), p. 886

${ }^{20}$ On various forms of VAT split payment implementation see the Deloitte study (2017) 'Analysis of the impact of the split payment mechanism as an alternative VAT collection method' ordered by the European Commission, available at https://ec.europa.eu/taxation_customs/sites/taxation/files/split_payment_report2017_en.pdf, p.4

${ }^{21}$ See La Grutta S. 2015, 'Split payment Mechanism for Public Bodies’, International VAT Monitor, (26) 2.
} 
currently mandatory for public agencies, companies controlled directly or indirectly by public authorities and specifically designated companies (like e.g. the Italian Stock Exchange) ${ }^{22}$. An even further reaching split payment mechanism entered into force in Poland on July $1^{\text {st }} 2018^{23}$, granting each and every buyer (payer) in B2B relations ${ }^{24}$, the option to select a split payment option for a non-cash payment order for the acquired goods or services, where the net value of the invoice would be transferred to the merchants "normal" current bank account, however the applicable VAT amount would be transferred to the merchants blocked VAT bank account ${ }^{25}$, which the merchant's bank is obliged to create and maintain for him ${ }^{26}$. The split payment operation may be performed automatically by a special settlement system which divides the payment and transfers it into two separate accounts; or manually by the taxpayers who make two separate transfers into two separate accounts ${ }^{27}$. The mechanism, fully optional at first, was subsequently changed by the Polish legislator as partially mandatory as of 1 November $2019^{28}$. The mandatory mechanism applies however only over a PLN 15000 (app. EUR 3500 ) threshold and only in case of certain pre-selected characters of merchants, i.e. those dealing with goods and services traditionally considered as more susceptible to VAT tax fraud like steel, fuel and coal, mobile phones, tablets, digital cameras and passenger car parts ${ }^{29}$.

\subsection{The intersection of payment services and split payment VAT collection}

The Council of the EU approved the Polish mandatory VAT split payment mechanism on the basis of the Council implementing decision of 18 February $2019^{30}$. Among the most important issues indicated in the Council decision was the fact that entities not established in Poland will also be covered by the mandatory split payment mechanism when carrying out the supplies of goods or services subject to the mandatory split payment in Poland and have to hold a bank account operated pursuant to Polish Banking Law. This however was considered as a measure not constituting a burden for the non-Polish entrepreneurs as they were in the opinion of the Council "not to incur any additional costs relating to the obligation of opening the bank account in Poland, since these taxable persons will be able to open and hold the bank account in Poland free of charge"31. This standpoint is naturally correct, however one should not forget that costs directly associated with the contracting of bank account services in Poland are not the only costs entrepreneurs previously not holding accounts with Polish banks (Polish-based branches of EU credit institutions) will have to incur. An additional cost and incommodity is in particular the obligation itself to alter settlement procedures for the sole purpose of B2B relations with Polishbased buyers.

\footnotetext{
${ }^{22}$ See art. 17 et seq. of the Italian VAT law, Decreto del Presidente della Repubblica del 26/10/1972 n. 633 Istituzione e disciplina dell'imposta sul valore aggiunto, Gazzetta Ufficiale n. 292 del 11 novembre 1972.

${ }^{23}$ On the basis of the Law of 15 December 2017 on the change of the law on tax on goods and services and selected other laws, Dz.U.2018.62 of 1 October 2018.

${ }^{24}$ The Split VAT collection mechanism in Poland is not applicable to C2B relations.

${ }^{25}$ From which the Merchant may without additional requirements and public consents transfer funds only for the purpose of performing tax payments.

${ }^{26}$ On the introduction of the VAT split payment in Poland see Michalik, T. and Przybylski M. 2018, 'Poland: Split payment in Poland is about to be launched.' International Tax Review. 7/30/2018, p. 1 and Guziejewska B. and Zajączkowski W. (2018), 'VAT split payment jako nowe narzędzie uszczelniania systemu podatkowego w Polsce', Research Papers of Wrockaw University of Economics (532): s. 135-143.

${ }^{27}$ Hoza B. and Żabka A. 2018, 'IT Tools Used to Reduce the VAT Loophole-JPK_VAT, STIR, Split Payment Mechanism', ASEJ - Scientific Journal of Bielsko-Biala School of Finance and Law, Volume 22, No 3 (2018), 29.

${ }^{28}$ On the basis of the Law of 9 August 2019 on the change of the the law on tax on goods and services and selected other laws, Dz.U. 2019.1731 of 13 September 2019.

${ }^{29}$ App. 150 groups of goods and services.

${ }^{30}$ Council implementing decision authorising Poland to introduce a special measure derogating from Article 226 of Directive 2006/112/EC on the common system of value added tax of 12 February 2019, 5849/19.

${ }^{31}$ Council implementing decision... recitals Pt. (9).
} 
The impact of the VAT split payment mechanism in the Polish model extends also beyond the obvious transaction participants buyer (payer) - bank - seller (payee). A significant amount of transactions (also in the market segments subject to mandatory split payment under Polish regulations are performed via electronic means and pertain to the everyday increasing e-commerce segment. For this reason, in most such cases there is yet another element present in the contracting/payment chain, i.e. the payment service provider intermediary through which the funds flow before they reach the bank account of the merchant. In most cases such intermediary does not hold a banking licence but a payment institution/emoney institution license. For this reason, despite being authorized to enter into possession of funds it can only open and hold a payment account ${ }^{32}$ for the user, and not a bank account. In the normal course of events the provision of a payment account to the user would be fully sufficient and a bank account would not be needed. Nevertheless if the merchant which the payment services provider is servicing falls under the "mandatory split payment list" and the transaction is above the threshold of PLN 15000 such provider will not be able ${ }^{33}$ process such payment and in consequence will not be able to service such merchant ${ }^{34}$.

It is therefore clear that aforementioned VAT split payment collection method impacts the process of collecting payments online by acquiring payment services providers. What is however important, the same cannot be said about the PIS providers. This is due to the fact that the PIS model does not envisage the intermediary (PIS provider) entering into possession of the funds during the transaction. As a matter of principle, funds are therefore not deposited on any other account then that of the final merchant. And the PIS provider, when entering the ebanking environment of the payer (buyer) is fully capable of issuing a payment order on his behalf in the VAT split payment model. This gives the PIS model of online payments a significant advantage over other competitive services, not only for this matter online PbL acquiring but also card payment acquiring. The two latter technologies should be expected to experience significant technological obstacles in this respect.

\section{Conclusion}

Arguments presented above provide yet another confirmation how tax law regulations can impact markets and services which originally or intentionally were not supposed to. An example of such rather unintended field of impact is the payment services market. Split payment VAT collection mechanisms, dependent of the form that is ultimately attributed to them by the national legislator may not only effect business decisions of merchants contracting bank services on national markets, but also their selection of payment technologies, and in consequence payment services providers. Due to the construction the Polish model of split payment VAT collection which requires the separate deposit of funds on dedicated VAT bank accounts, it clearly favorizes PIS services over competing alternatives. This in turn can in the future, even to a greater extent, contribute to their popularization and parallel decline of 'traditional' online PbL acquiring.

\footnotetext{
${ }^{32}$ Beit as a separate payment service or an element of the acquiring payment service.

${ }^{33}$ Whereas technically a possibility to process such payment via and acquiring payment services provider would be imaginable, in practice it will not happen (nor has it happened to this date) due to the high IT related costs necessary to incur on the side of the bank and the payment services provider. Such costs are rather not expected to outweigh the expected advantages and revenues related with the servicing of split VAT payment transactions.

34 This is actually a problem, which extends beyond the sphere of ecommerce payments, as the obligation to perform a split payment for goods and services from the "mandatory split payment list" over the PLN 15000 threshold de facto excludes the possibility to make a card payment in case at a fixed point of sale. The only option for the contracting parties is therefore either a cash payment of a traditional credit transfer.
} 


\section{(Mic 2019}

\section{References}

Communication from the commission to the European Parliament, the Council and the European Economic and Social Committee on the future of VAT: Towards a simpler, more robust and efficient VAT system tailored to the single market, 2011, Brussels, 6.12.2011, COM(2011) 851 final

Communication from the Commission to the European Parliament, the Council and the European Economic and Social Committee on an action plan on VAT: Towards a single EU VAT area Time to decide (2016), Brussels, 7.4.2016, COM(2016) 148 final.

de la Mano, M. and Padilla J. 2019, 'BIG TECH BANKING' Journal of Competition Law \& Economics, 14(4), 494-526,

Deloitte study (2017) 'Analysis of the impact of the split payment mechanism as an alternative VAT collection method' ordered by the European Commission, available at https://ec.europa.eu/taxation_customs/sites/taxation/files/split_payment_report2017_en.pdf

Guziejewska B. and Zajączkowski W. 2018, 'VAT split payment jako nowe narzędzie uszczelniania systemu podatkowego w Polsce', Research Papers of Wrocław University of Economics (532); s. 135-14

Hoza B. and Żabka A. 2018, 'IT Tools Used to Reduce the VAT Loophole-JPK_VAT, STIR, Split Payment Mechanism', ASEJ - Scientific Journal of Bielsko-Biala School of Finance and Law, Volume 22, No 3 (2018), 26 - 31;

Huizinga, H. 2002,'A European VAT on financial services?’, Economic Policy 17(35), pp. 497-534.

La Grutta S. 2015, 'Split payment Mechanism for Public Bodies', International VAT Monitor, (26), No. 2.

Mackenzie A. 2015 ‘The fintech revolution’, London Business School Review 26(3),

Mansfield-Devine, S. 2016, 'Open banking: opportunity and danger’, Computer Fraud \& Security (10), $8-13$,

Michalik, T and Przybylski M. 2018, 'Poland: Split payment in Poland is about to be launched.' International Tax Review. 7/30/2018

Paris R. 2003. 'The Globalization of Taxation? Electronic Commerce and the Transformation of the State’, International Studies Quarterly (2003) 47, 153-182

Stolarski, K. 2018, 'Bank account infrastructure as an indispensable means to provide financial services - the essential facilities doctrine revisited.' European Competition Law Review 39(3),

Study and Report (2018) on the VAT Gap in the EU-28 Member States: 2018 Final Report TAXUD/2015/CC/131, published in Warsaw, Poland on September $11^{\text {th }}$ 2018, available at https://ec.europa.eu/taxation_customs/sites/taxation/files/2018_vat_gap_report_en.pdf,

Zídková H, Št’astná A. 2019. 'VAT Collection Methods'. Acta Universitatis Agriculturae et Silviculturae Mendelianae Brunensis, 67(3): 883-895 